\title{
LEGAL GUIDE TO INTERNATIONAL BUSINESS TRANSACTIONS by Philip
}

Raworth (Canada: Carswell, 1991)

The internationalization of business is one of the dominant features of commerce in our present world...neither the legal profession nor the business community as a whole seems to be fully aware of the scope and importance of the legal aspects of international business.'

With these thoughts, Philip Raworth introduces his book, Legal Guide to International Business Transactions. The underlying theme of Raworth's book is that lawyers can and should play a wider role in advising clients on international business transactions. Lawyers, according to Raworth, tend to view their role in "too traditional and confined a way, contenting themselves with the modest and ancillary task of drawing up the legal documents needed to complete the transactions." ${ }^{2}$ Clients often consult their lawyers only after the decision has been made to export to a particular country and the legal framework ${ }^{3}$ in which the export will take place has been negotiated. Yet, there are many legal issues inherent in these decisions. To make a sound exporting decision, the client needs to consider issues such as the financial aspects of the transaction (including currency issues), financing modes and payment mechanisms, technical regulations in the export market, investment or competition rules, taxation rules, unfair trade duties and intellectual property protection. A lawyer in an international transaction must counsel the client in these matters before taking up the traditional role of scrivener.

As often as lawyers view their roles too narrowly, clients fail to realize that they need legal advice in the planning stages of an international business transaction. Raworth's book is intended to, as the title suggests, assist both business people and lawyers to gain familiarity with the legal aspects of an international business transaction. It addresses both the legal and business issues inherent in an international transaction.

The text tackles a wide range of issues in the form of a guide; it is not an in-depth discussion of the issues. In a sense, Raworth's book can be read almost like a checklist. A thorough reading of Legal Guide to International Business Transactions will go a long way in ensuring that a lawyer is aware of the issues inherent in such a transaction. However, the "checklist" style of the text means that a lawyer unfamiliar with an international transaction will soon have to turn to other sources to flesh out the details. To make this further research easier, a bibliography is appended to the end of each chapter.

Raworth uses many specific examples to illustrate his thoughts. Most of these examples are from the European community. However, the majority of Canadian exporters export to the United States, with Asia as an emerging market as well. Thus, the European community examples, while instructive, may not be directly serviceable for the majority of lawyers counselling exporting clients. Publishing Canada, 1991).

3. I.e., direct export, agency, distribution agreement, license, production in foreign market etc. 
The text contains over one hundred and fifty pages of tables and excerpts from international treaties, including the GATT Agreement on Government Procurement, the Paris Convention for the Protection of Industrial Property and the Convention of the Settlement of Investment Disputes Between States and Nationals of Other States (ICSID). As well, there are numerous references to and quotations from international treaties and domestic statutes. Researchers of international law will find this collection most useful and convenient.

The book is arranged under the four "P's": Product, Place, Price and Promotion. While this is catchy, the topics do not clearly align themselves under these topics. Issues will be touched on in a number of chapters. A lawyer looking for a discussion of a particular issue will have to scan through the whole text.

Raworth provides an interesting discussion on choice of law and arbitration in his section on Dispute Settlement. ${ }^{4}$ Choice of law is an important consideration but one many lawyers pay little attention to. Indeed, these two topics are often the last considerations, ending up in the "boiler plate" clauses. Very often a firm's standard clauses are inserted without too much thought. Raworth rightly urges lawyers to give greater attention to choice of law clauses.

In his discussion of dispute settlement, Raworth raises a number of practical matters which will influence a client's decision on arbitration or litigation. Alternate Dispute Resolution, or "ADR," is in vogue for all kinds of disputes. As a result, many discussions of ADR fail to raise possible problems. Raworth raises some of the pluses and minuses in using ADR versus litigation.

There are a variety of established international dispute settlement mechanisms available and it is important to select the one most beneficial to one's client. Raworth discusses some of these and includes, as examples in the Appendices, the Center for Public Resources Model Procedure for Settlement of Transactional Business Disputes and the ICSID Convention. The ICSID Convention is of current interest as the new dispute resolution mechanism for investment disputes under the North American Free Trade Agreement (NAFTA) makes use of ICSID, as well as the UNCITRAL Arbitration Rules, which are also briefly discussed by Raworth.

Raworth's organization of the issues and his comments throughout stress the need for informed advance planning of an international business transaction. While this is true for any commercial transaction, it is particularly true for an international transaction. Foreign 
laws, currencies and practices, plus the impact of international treaties, make advance planning even more crucial. Raworth's book will be a good start for lawyers who are planning an international transaction.

Shawna K. Vogel

Barrister \& Solicitor

Edmonton, Alberta 